\title{
Performance Analysis of Photovoltaic Module by Dust Deposition in Western Rajasthan
}

\author{
Anil Kumar Sisodia ${ }^{1,2, *}$ and Ram Kumar Mathur ${ }^{1,3}$ \\ 1Department of Physics, Samrat Prithviraj Chauhan Government College, Ajmer \\ (Rajasthan), Affiliated to Maharshi Dayanand Saraswati University, Ajmer, Rajasthan, \\ India \\ 2Department of Physics, Government Bangur PG College, Pali, Rajasthan, India \\ ${ }^{3}$ Department of Physics, Dayanand College, Ajmer (Rajasthan), Affiliated to Maharshi \\ Dayanand Saraswati University, Ajmer, Rajasthan, India
}

Article Type: Article

Article Citation: Anil Kumar Sisodia, Ram Kumar Mathur. Performance

analysis of photovoltaic module by dust deposition in Western Rajasthan. Indian Journal of Science and Technology. 2020; 13(08),921-933.D0l:10.17485/ijst/2020/ v013i08/149928

Received date: January 23, 2020

Accepted date: February 12, 2020

*Author for correspondence: Anil Kumar Sisodia anilsisiitd@ yahoo.co.in 9 Department of Physics, Samrat Prithviraj Chauhan Government College, Ajmer (Rajasthan), Affiliated to Maharshi Dayanand Saraswati University, Ajmer, Rajasthan, India

\begin{abstract}
Background: Dust soiling is a main contributing environmental issue with the climatic condition of Western Rajasthan that influences adversely the performance of solar PV technology. The deposition of dust particles reduces the solar output by hampering the solar radiation. Objectives: To explore the trend of dust soiling rate over different seasons in a year and its impact on the performance of solar photovoltaic (PV) system in Western Rajasthan in India. Especially, dust particle settlement is primarily affecting the optical properties of the PV modules, which results in declining their output electrical energy yield. Thus, it adds significantly to quantify the effect of soiling by measuring transmittance losses and soiling ratio with different dust particles. Methods: This article presents a significant loss in output energy yield of photovoltaic system with the layer by layer deposition of the different dust particles in Western Rajasthan. In the context of physical properties, the XRD and SEMEDS analysis of the collected dust sample from SOTA is carried out, and also the dust particle size study has been performed in order to observe the sediment characteristics of various dust samples in Western Rajasthan. The preliminary results depict the optical (glass transmittance) and electrical (soiling ratio) parameters strongly depend on the dust properties and its deposition density. Findings: With this consideration, the highest power loss is observed in the Bikaner dust sample (S1) due to its high transmittance loss (96.1\%) and whiles the minimum for Barmer (78.4\%). Applications: This study can be useful to guide the appropriate level of dust soiling mitigation on solar PV systems in an arid or particular region. It can also be decided on the optimal cleaning schedule in actual conditions in the year.
\end{abstract}

Keywords: Dust Soiling, Desert, PV Module, Air Pollution, Solar Energy, Transmittance, Soiling Ratio. 


\section{Introduction}

The performance of a photovoltaic (PV) energy system is highly influenced by the capacity of the solar radiation collection on the front glass surface of PV modules. The output maximum power collection capacity deciding by the intensity of received solar radiation, plate, tilt angle, orientation, and some other environmental factors, such as temperature, wind velocity, properties of solid materials (dust and bird dropping), the shadow of passing clouds, pollutants, and cleanness as shown in Figure 1 [1-4].

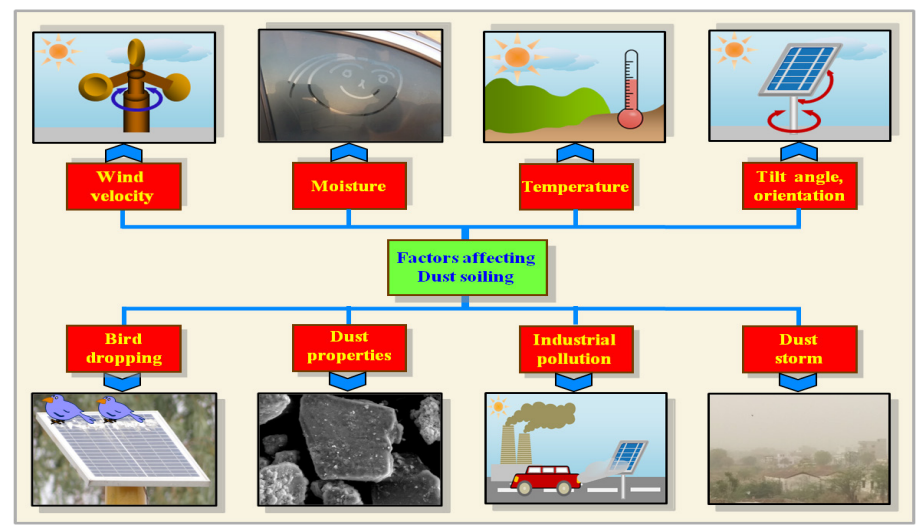

FIGURE 1. Outline of main dust soiling effects.

This study presents the qualitative analysis of the collected dust particles from SOTA. In addition to that, the soiling ration has been determined to observe the effect of different dust particles on the PV system in Western Rajasthan. The climatic condition of western Rajasthan (Barmer, Bikaner, Jaisalmer, and Jodhpur) is characterized as semi-arid, regular dust storm, short rainfall, and high temperature. The Western desert part strongly faces the dust accumulated from various sources like dust, cement \& lime industries, mining, and biomass burning in the year. Air quality and visibility in the atmosphere are affected by this dust sources. A typical dust soiling on the flat plate PV module in western Rajasthan is shown in Figure 2.

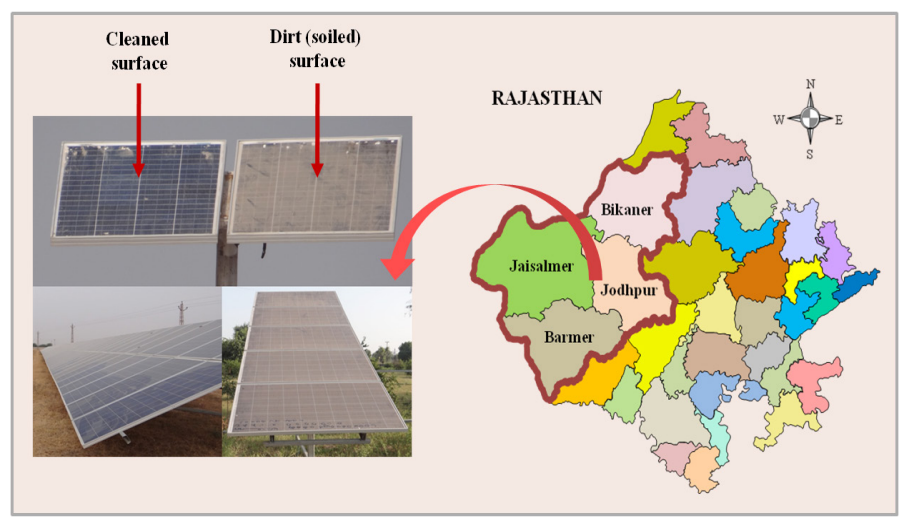

FIGURE 2. Dust soiling on PV modules plates in Western Rajasthan. 
In [5-6] western Rajasthan, more importantly, the harsh environmental conditions such as high temperature (around $40-50{ }^{\circ} \mathrm{C}$ in summer), high levels of atmospheric dust, and sand storm are the main challenges that restrict the solar PV output. In a study, high concentrations of Particulate Matter (PM2.5 and PM10) were examined in winters whereas little concentrations during monsoon months. It is also revealed that the dust mainly creates from the arid and desert parts of the world [7-10].

Dust storms start from the 'Thar' Desert located in the western parts of Rajasthan. In the Western desert, the dust storms are developed, mainly during the summer season (March-April), with the least rainfall. The loose dust particles uplift in the atmosphere that is shifted through westerly winds over the Western part of Rajasthan [11].

The performance of a solar collector declines more and more as dust is deposited on its front surface [12-16]. A significant loss in the efficiency of PV modules is observed for sand, dust accumulation up to $1 \mathrm{~g} / \mathrm{m}^{2}$ [17].Moreover, a 50\% loss is reported in the PV power output after six months of outdoor exposure in Dhahran-KSA [18-19]. In Ref. [20], Ilse et al. provided a thorough study of macroscopic and microscopic factors relating to soiling. Many previous studies discuss a vast analysis of key issues, including airborne dust particle concentrations, dust characteristics (compositional analysis, and size distribution), and particle deposition rates on systems. Moreover, Goossens [21], presented in his work the rate of dust settlement on the PV surface depends on a number of factors including the concentration of dust particles in the atmosphere, the intensity of the winds transporting the dust, as well as geographic and surface condition of the depositional environment [22].

\section{Effect of Dust on Solar PV Panel}

Smaller solid dust particles are the most detrimental agent present in the Western Rajasthan environmental condition. The monthly average power loss by dust soiling is shown in Figure 3 [23]. The solar energy outdoor testing area (SOTA) is located in Jodhpur, Western Rajasthan. When soil particles have settled on the PV module's surface, they interfere with illuminated power by the effect of attenuating and scattering of incident solar radiation. It is a most common practice that the panels are commonly installed at the height in outside environment location, where rainfall is only the most efficient natural cleaning agent for removing dirt from panels in the whole year. Hence, the optimal cleaning of the module surface depends only on the frequency and amount of the rainfall on that system's site. Particularly in the western Rajasthan, a weak intensity and less frequency of rainfall have led to the constant deposition of considerable amounts of dust onto the panel's surface.

Western Rajasthan has four seasons in which December to February is winter; March to June is summer; July to September is rainfall (monsoon), and October to November is retreating monsoon. Generally, it is seen that the dust is washed away by low rainfall. In the study, it is inferred that the strongest power losses observed just after winter i.e., in January ( $35 \%)$ while minimum power losses in monsoon season $(\sim 1 \%)$ as demonstrated in Figure 3. At the present, rainy season (monsoon) is typically started from the month of late June and continues till the end of September in Western Rajasthan. Thus, during rainfall, panels will get almost clean and thereby power losses due to dust accumulation will almost 


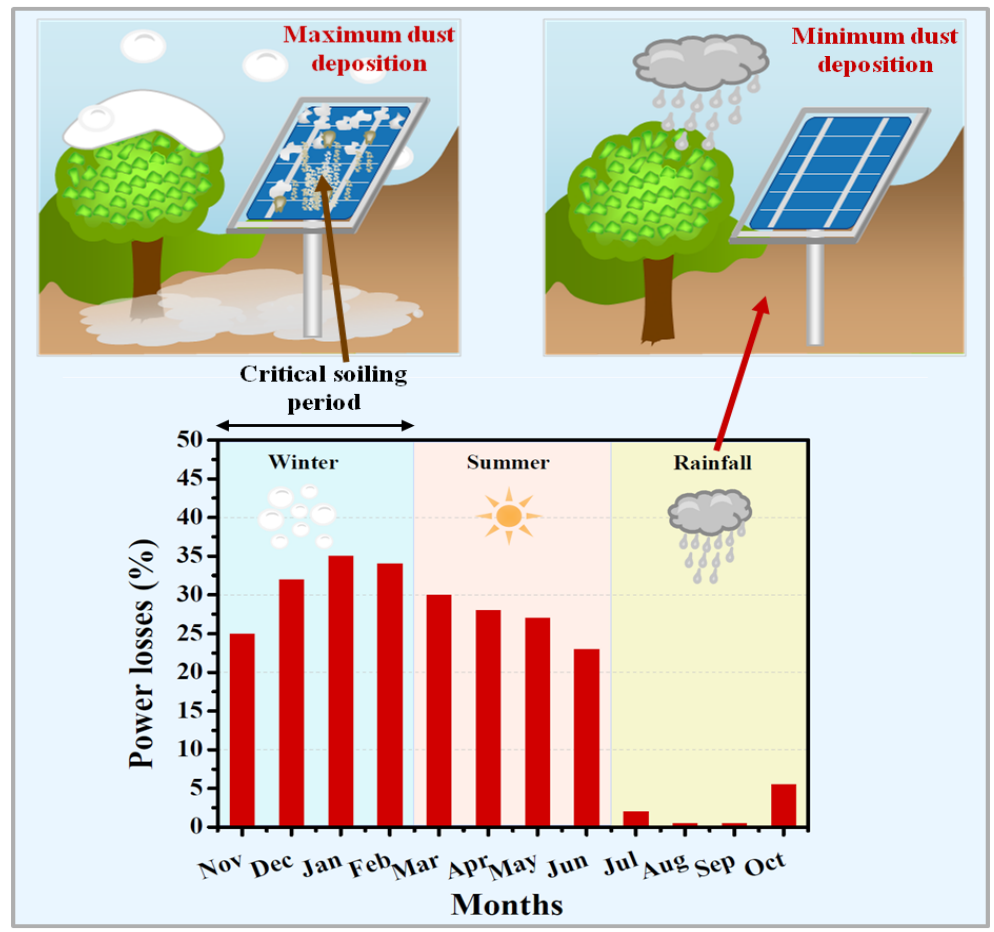

FIGURE 3. Monthly average power loss by dust soiling.

get down. After the departure of monsoon, once again dust accumulation will start-up and continues till the end of winter, i.e., resulting in power losses that reach up to its greatest level.

In arid zone, the prevailing moisture in the air, this keeps helping to promote the sustainability of dust deposition continuously with the strong adhesion on flat surfaces and this leads to loss of solar output in winter maximum. It is also clear that after winter, the arrival of summer along with high wind velocity (which is termed as "loo") causing erosion of dust particles will take place with losing adherence from the glass surface. Hence, the power loss cuts somewhat during the arrival of summer [24].

\section{Dust Characterization}

\subsection{Chemical Composition}

In perspective of the mineralogical composition analysis, a chemical analysis was performed by the X-ray diffraction (XRD) technique to investigate mineral built of element composition. The quantitative analysis has been investigated using Pan analytical X-ray-Diffractometer software. On the basis of the result as depicted in Figure 4, the collected dust particles from the solar energy outdoor testing area (SOTA) were composed mostly of quartz $\left(\mathrm{SiO}_{2}\right)$ followed by calcite $\left(\mathrm{CaCO}_{3}\right)$ and some amount of other mineral feldspars $\left(\mathrm{CaAlSi}_{2} \mathrm{O}_{8}\right)$ and berlinite $\left(\mathrm{AlPO}_{4}\right)$. Quartz and feldspar are the most common 
compositions found in dust. For understanding the chemical composition of dust particles, the XRD results show that the major peaks of quartz, feldspar, calcite, dolomite, pyroxene, and berlinite, which corresponds with other reported study [25-27].

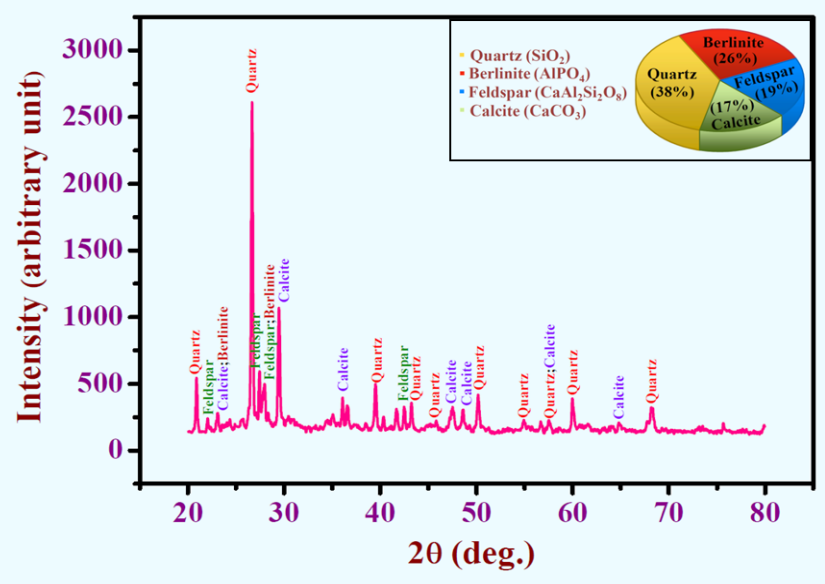

FIGURE 4. X-ray diffraction pattern of dust sample for chemical composition analysis.

\subsection{Dust Morphology}

The morphological assessment of the solid dust particles was carried out by the SEMEDX technique. A scanning electron microscope BRUKER was employed to investigate the microstructure of the various dust particles. The SEM is also equipped with Energydispersive X-ray spectroscopy (EDX) detector by EDAX, which was used for elemental analysis of dust particles.

It is apparent from Figures 5 and 6 that the dust sample was subjected by spherical, irregular, tubular, long and prismatic, porous, and crystalline shapes of particles. The various shapes and sizes of the particles in dust samples might be due to various sources,
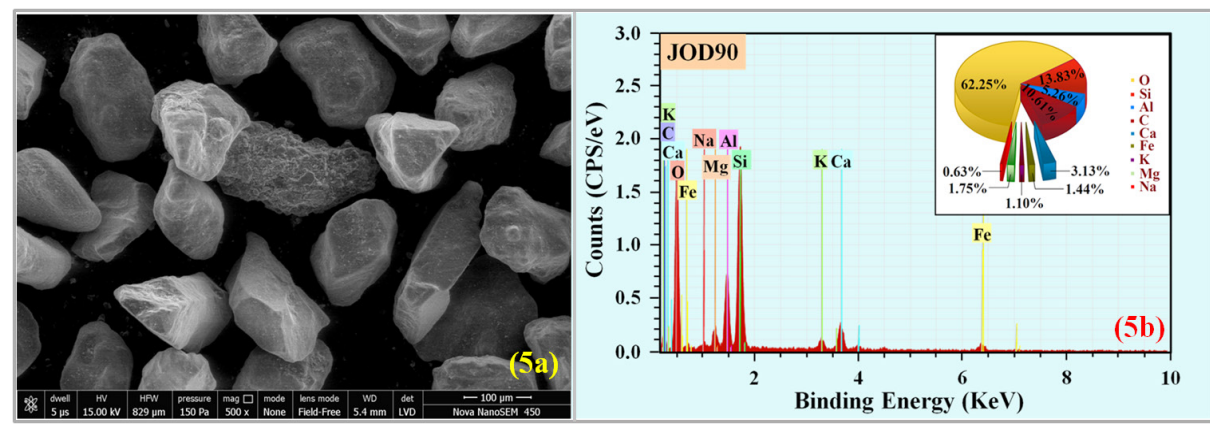

FIGURE 5. (a) SEM micrograph images of Dust sample and, (b) A typical EDAX spectra of elemental analysis of the dust samples collected from the SOTA. 


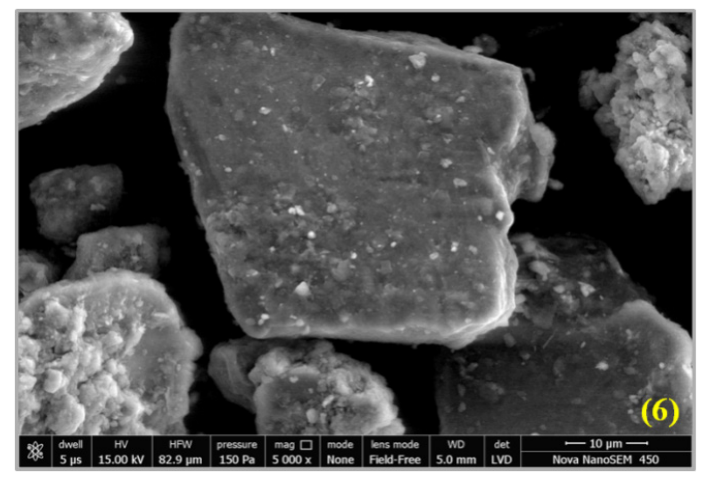

FIGURE 6. SEM micrograph of dust in which, small carbonate particles adhered with smooth quartz particles.

geological characteristics, local sources (like; traffic, construction, industrial, etc.), land use and land cover pattern, and meteorological parameters.

Elemental data analysis of dust samples shows that the particles contain mostly Si, $\mathrm{Al}$, $\mathrm{C}$, and $\mathrm{Ca}$ with a minority of particle $\mathrm{Fe}, \mathrm{K}, \mathrm{Mg}$, and $\mathrm{Na}$. Our dust prosperous in mainly quartz, carbonates, and feldspar usually originated from local sources. It is also stated in the dominance of quartz followed by feldspar, calcite, chlorite, and plagioclase in aerosol samples at the north-western part of India neighbouring "Thar Desert” [28-29]. Calcium carbonate or limestone is recognized to cement works (i.e., shows the presence of the cement industry in the local area) present in the local environment. Moreover, (Si, Al) and $(\mathrm{Mg}, \mathrm{Na})$ are concerned with the desert dust \& sea salt-related sources correspondingly.

\section{Experimental Methodology}

\subsection{Particle Size Analysis}

This research aims to characterize and size-analyze the settled dust particles on the glass surface and their negative effect on system performance. Thus, a study of the particle size analysis on the PV module surface is important. In this framework, an effort is taken out to categorizing and evaluating the effect of particle size of dust samples. In artificial soiling experiments [30], Mani et al. investigated the relative percentage of the standard particle size of soil samples collected from Sekhawati region of Rajasthan (India).

In our experimental study, dust samples were collected from four different locations Barmer (S1), Bikaner (S2), Jaisalmer (S3), and Jodhpur (S4) in Western Rajasthan.

The results of the composition analysis of particle size attributed that collected dust samples S1, S2, S3, and S4 contain a high concentration of $125 \mu \mathrm{m}$ diameter particle size as shown in Table 1. In western Rajasthan (semi-arid), the main proportion of dust soiling is revealed to dust particles in the very fine sand range (particle diameter between 63 and $125 \mu \mathrm{m})$. 
TABLE 1. Sediment type distribution of collected dust samples

\begin{tabular}{lccccc}
\hline Sediment type & Size $(\boldsymbol{\mu m})$ & S1 (\%) & S2 (\%) & S3 (\%) & S4 (\%) \\
\hline Medium silt & $16-31$ & 8.82 & 1.01 & 1.00 & 1.32 \\
Coarse silt & $31-36$ & 5.91 & 4.06 & 5.82 & 4.37 \\
Very fine sand & $63-125$ & 79.41 & 93.21 & 77.62 & 75.91 \\
Fine sand & $125-250$ & 5.87 & 1.72 & 15.56 & 18.40 \\
\hline
\end{tabular}

\subsection{Dust Sample Analysis}

In the current study, the dust samples were collected from different locations (Barmer, Bikaner, Jaisalmer, and Jodhpur) in Western Rajasthan. To replicate the effect of dust particle size on the front PV module surface, all dust samples were sieved with a mesh size no. $125 \mu \mathrm{m}$ as shown in Figure 7.

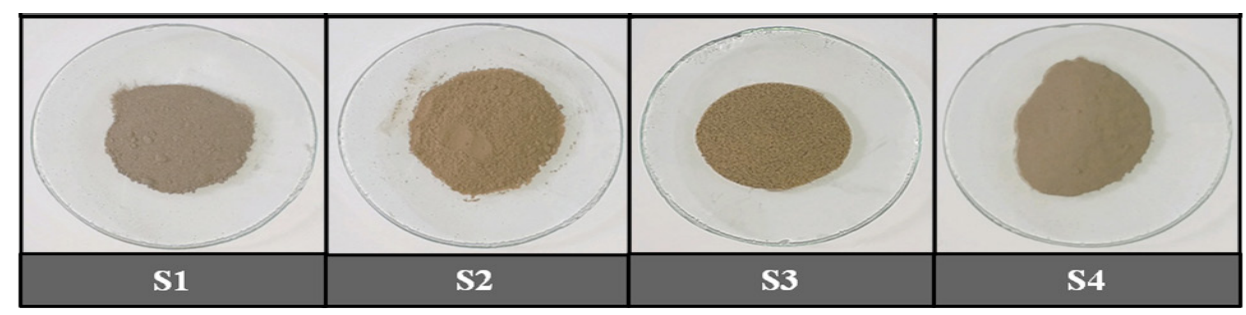

FIGURE 7. Collected dust sample from various locations of Western Rajasthan (Barmer, Bikaner, Jaisalmer, and Jodhpur).

\subsection{Apparatus Description}

\subsubsection{Solar Power Output Study}

For the investigation of electrical performance (solar power output) with different dust deposition on the PV module surface, the experimental arrangement requires various types of equipment to obtain the results as Solar PV module Analyzer (PROVA 210); dust samples: (a) Barmer S1, (b) Bikaner S2, (c) Jaisalmer S3, (d) Jodhpur S4; and weighing scale to determine the dust quantity. The experimental setup is shown in Figure 8a.

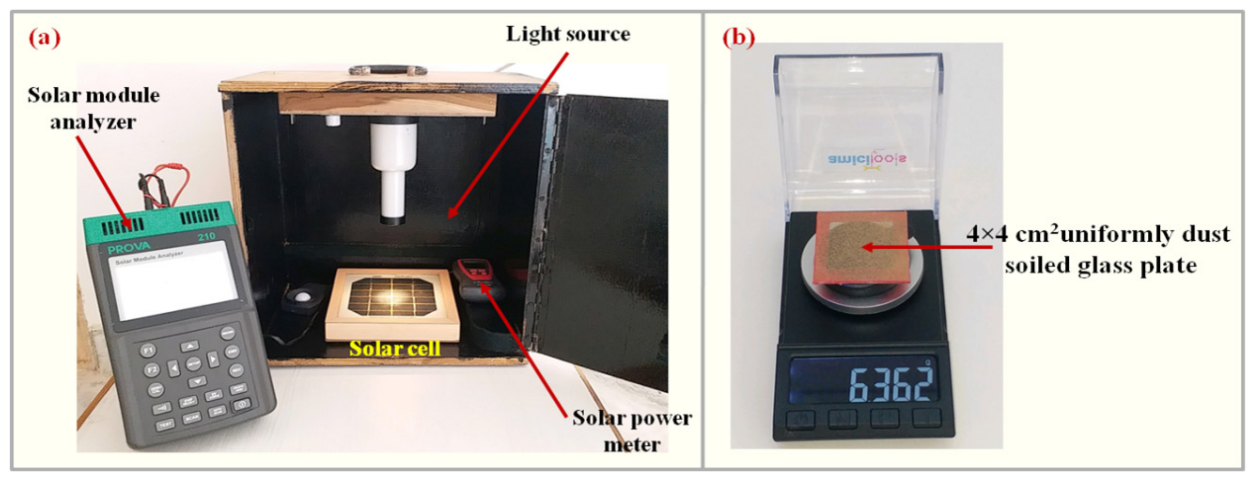

FIGURE 8. (a) Experimental setup used to present electrical study and, (b) The weighing scale is used in present study for the dust density measurement. 


\subsubsection{Dust Gravimetric Density Measurement}

The glass slides of area $4 \times 4 \mathrm{~cm}$ were used to determine the dust density. The dust density measurements are done by calculating the difference in weight of the slides before and after deposition divided by the area of the glass slides. The measurements are carried out by using Amici tools high precision digital scale (8068 series, resolution $0.001 \mathrm{gm}$ ) as depicted in Figure $8 \mathrm{~b}$. The soil gravimetric density is measured in $\mathrm{g} / \mathrm{cm}^{2}$.

$$
\operatorname{SGD}\left(\mathrm{g} / \mathrm{cm}^{2}\right)=\left(\frac{\mathrm{M}_{\text {soiled }}-\mathrm{M}_{\text {clean }}}{\mathrm{A}}\right)
$$

\subsubsection{Transmittance Measurements}

The normal transmittance measurements through the glass samples were carried out at the indoor laboratory with the set-up shown in Figure 9a. The apparatus comprises a yellow halogen light (equivalent to sunlight) of visible spectra $(555 \mathrm{~nm})$ range, and dust-soiled glass plate samples $(4 \mathrm{~cm} \times 4 \mathrm{~cm})$. The average values of the normal transmittance intensity of light $\left(\mathrm{W} / \mathrm{m}^{2}\right)$ were measured by using a MECO solar power meter [13] on the glass plate corresponding to 5 spots as shown in Figure $9 \mathrm{~b}$.

Collected dust particles were spread uniformly over the glass coupon using a flour strainer with sieve size no. $125 \mu \mathrm{m}$ onto the $4 \times 4 \mathrm{~cm}^{2}$ glass plate, and transmittance analysis performed under the artificial lightning source (light intensity at the radiation level of $\left.650 \mathrm{~W} / \mathrm{m}^{2}\right)$.

\section{Result and Discussions}

\subsection{Electrical Performance Study}

The effect of various collected dust particles from Western Rajasthan on solar power output has been examined. The power output of solar PV modules is obtained with four

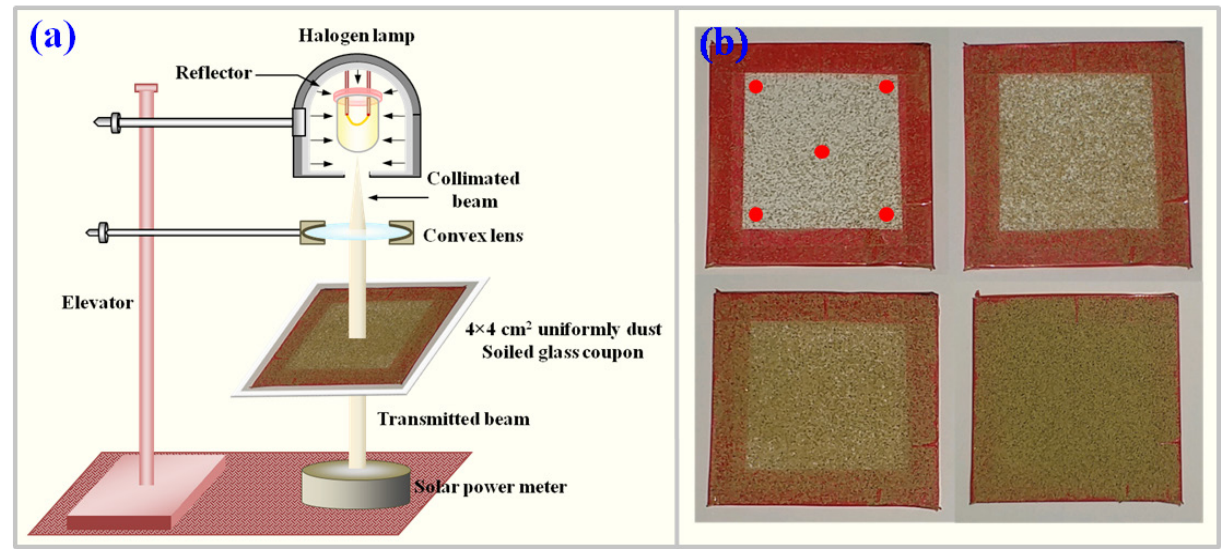

FIGURE 9. (a) Schematic diagram of the apparatus used for measuring the glass normal transmittance and, (b) transmittance of the samples was evaluated at the 5 different locations (i.e., red dots) in the glass sample. 
(S1, S2, S3, and S4) different dust samples having different weights (dust density $\mathrm{g} / \mathrm{cm}^{2}$ ) by detecting in output power measurements $P_{\max }\left(\right.$ i.e., $P_{\mathrm{mpp}}$ ) [31-33]. A comparative study of collected dust samples has been performed with different dust densities and the results are described in Figure 10. The soiling loss (SL) is calculated as per the equation (2) given below:

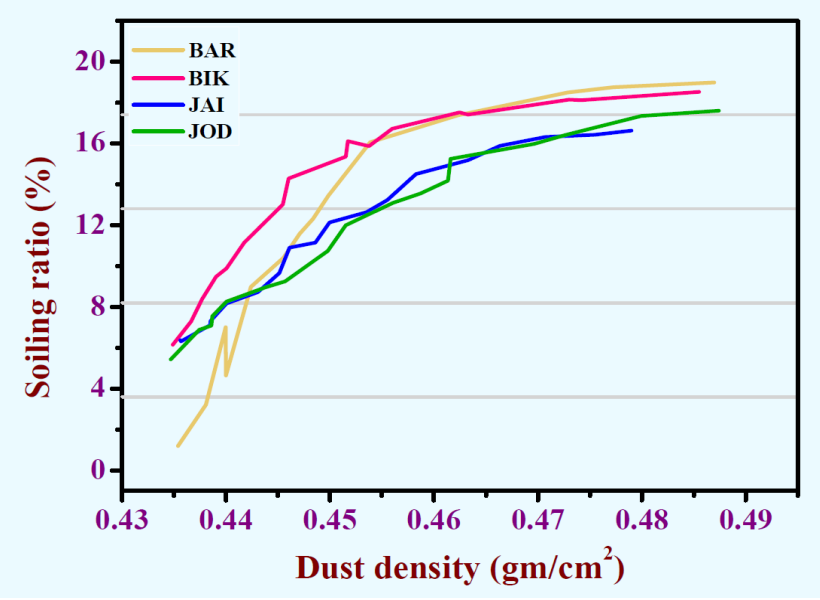

FIGURE 10. Effect of different dust samples on power losses.

$$
\operatorname{SR}(\%)=\left(1-\frac{P_{\text {soiled }}}{P_{\text {cleaned }}}\right) \times 100
$$

It can be practically seen that the deposition of dust particles on the solar PV module obstructs the sunlight and hence turn down the power to a large extent. The result from Figure 10 indicates the power loss due to dust accumulation on the PV surface [34-37]. As data summarized that in the case of the Bikaner dust sample (S2), the maximum power loss has been detected.

\subsection{Optical Performance Study}

An extensive experimental study regarding the effect of different dust particle samples on transmittance through the glass plate has been performed. Glass plates were artificially exposed to different dust particles. Measurements of normal transmittance through these soiled glass plates were taken and compared with that of a clean plate. In this way, measured output transmittance is the direct characteristics of receiving sunlight after being blocked due to an amount of dropping through each spot. An additional reduction in the intensity of transmittance radiation causing the dust accumulation can be calculated by the output transmittance losses (\%) as follows:

$$
\text { Transmittance losses }(\%)=\frac{\text { Trans }_{\text {clean glass plate }}-\text { Trans }_{\text {bird dropping }}}{\text { Trans }_{\text {clean glass plate }}} \times 100
$$


The average reduction in transmittance for various dust deposition samples (S1, S2, S3, and S4) is plotted in Figure 11. The loss in transmittance is directly affected by the accumulation of dust on the glass surface. In fact, as the dust density increases, the transmittance loss also rises rapidly, and it hikes until reaching its upper limit. Thereafter, the effect of dust accumulation vanishes.

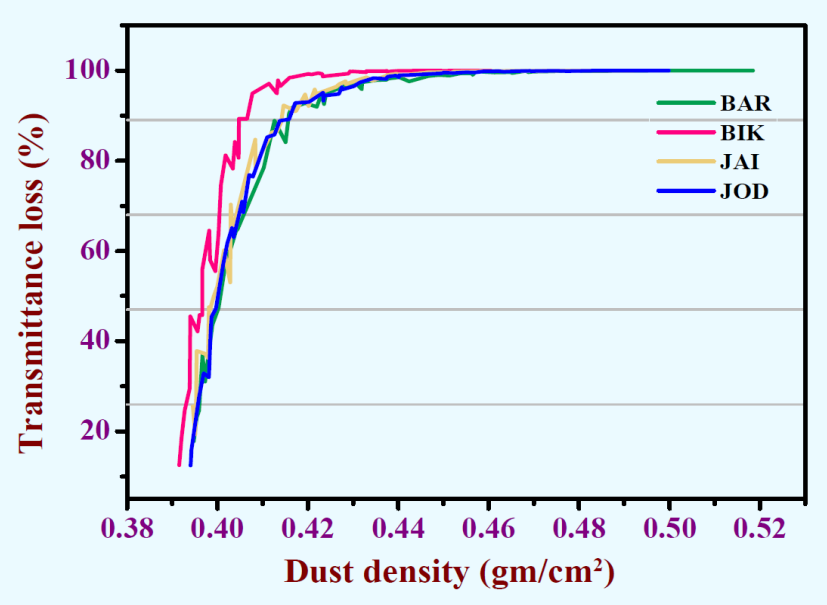

FIGURE 11. Transmittance reduction as a function of dust deposition density.

As a result, it is evident that a high percentage of very fine sand particles (compared to dust from other sites) were seen in Bikaner dust (S2, 93.21\%), which means that there were smaller gaps between these very fine particles through which light can pass [38]. Hence, it is indicated in the transmittance loss, where Bikaner shows higher loss compared to other locations as shown in Figure 12.

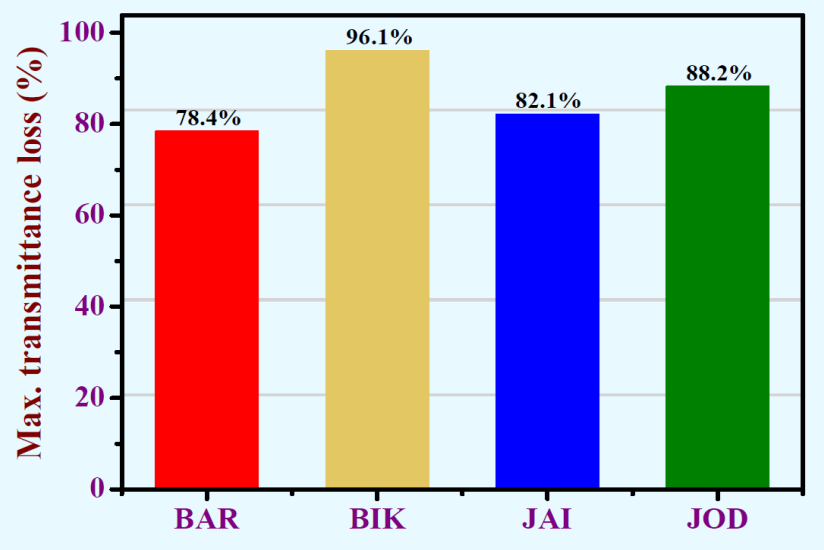

FIGURE 12. Maximum transmittance losses for different dust samples. 


\section{Conclusions}

As regional areas show the main source of dust fallout, while local sources contribute significant amounts. In concern to qualitative analysis, Carbonates and quartz are the main sources of dust in western Rajasthan; while feldspar is present in significant amounts.

In order to quantitative analysis, the effect of a different dust particle, a comparative study of a total off our dust samples has been carried out with different dust sample weights (gravimetric density). Dust samples are collected from different geographical locations in Western Rajasthan. These dust samples were artificially deposited on solar glass samples. Soiling loss due to dust, $P_{\max }$ was used to evaluate the performance of the soiled glass samples of solar cells. It is concluded that a small layer of dust particles can reduce the PV output power to a large extent. A maximum reduction in power is obtained for the Bikaner dust sample (S1) due to its high transmittance loss (96.1\%). It is caused by the presence of a high percentage of very fine sand particles, this confirms that the smallest particle blocks more sunlight and thus reduces the performance of solar PV modules.

\section{Acknowledgments}

The authors thank the IIT Jodhpur; Dept. of Physics, Samrat Prithiviraj Govt. College, Ajmer (MDS University, Ajmer); and DRDO, Jodhpur for their kind support and help.

\section{References}

1. Elminir HK, Ghitas AE, Hamid RH, El-Hussainy F, Beheary MM, Abdel-Moneim KM. Effect of dust on the transparent cover of solar collectors. Energy Conversion and Management. 2006, 47, 3192-3203. DOI: 10.1016/j.enconman.2006.02.014.

2. Mustafa RJ, Gomaa MR, Al-Dhaifallah M, Rezk H. Environmental impacts on the performance of solar photovoltaic systems. Sustainability. 2020, 12, 608. DOI: 10.3390/su12020608.

3. Styszko K, Jaszczur M, Teneta J, Hassan Q, Burzyńska P, Marcinek E, Lopian N, Samek L. An analysis of the deposition on solar photovoltaic modules. Environmental Science and Pollution Research. 2018, 26(9), 8393-8401. https://doi.org/10.1007/s11356-018-1847-Z

4. Ghazi S, Sayigh A, Ip K. Dust effect on flat surfaces - a review paper. Renewable and Sustainable Energy Reviews. 2014, 33, 742-751. http://dx.doi.org/10.1016/j.rser.2014.02.016

5. Bhaskar BV, Mehta VM. Atmospheric particulate pollutants and their relationship with meteorology in Ahmadabad. Aerosol and Air quality Research. 2010, 10, 301-315. DOI: 10.4209/ aaqr.2009.10.0069.

6. Charan PD, Sahel H. Study of respirable dust in ambient air of Bikaner city and its impact on human health. Applied Journal of Hygiene. 2014, 3, 11-14. DOI: 10.5829/idosi.ajh.2014.3.1.74133.

7. Duce RA. Sources, distributions, and fluxes of mineral aerosols and their relationship to climate. Dahlem workshop on aerosol forcing of climate, John Wiley: Chichester, UK. 1995; 43-72. https://hero.epa.gov/hero/index.cfm/reference/details/reference_id/2100

8. Ginoux P, Prospero JM, Gill TE, Hsu NC, Zhao M. Global-scale attribution of anthropogenic and natural dust sources and their emission rates based on MODIS Deep Blue aerosol products. Reviews of Geophysics. 2012, 50, RG3005. https://doi.org/10.1029/2012RG000388 
9. Kohfeld KE, Harrison SP. DIRTMAP: the geological record of dust. Earth-Science Reviews. 2001, 54(1-3), 81-114. https://doi.org/10.1016/S0012-8252 (01)00042-3

10. Middleton NJ. Geography of dust storms in south-west Asia. Journal of Climatology. 1986, 6(2), 183-196. https://doi.org/10.1002/joc.3370060207

11. Sarkar S, Chauhan A, Kumar R, Singh RP. Impact of deadly dust storms (May 2018) on air quality, meteorological, and atmospheric parameters over the northern parts of India. GeoHealth: Advancing Earth and Space Science. 2019, 3, 67-80. https://doi.org/10.1029/2018GH000170

12. Weber B, Quinones A, Almanza R, Duran MD. Performance reduction of PV systems by dust deposition. Energy Procedia. 2014, 57, 99-108. https://doi.org/10.1016/j.egypro.2014.10.013

13. Rao A, Pillai R, Mani M, Ramamurthy P. Influence of dust deposition on photovoltaic panel performance. Energy Procedia. 2014, 54, 690-700. https://doi.org/10.1016/j.egypro.2014.07.310

14. Mejja F, Kleissl J, Bosch JL. The effect of dust on solar photovoltaic systems. Energy Procedia. 2014, 49, 237-2376. https://doi.org/10.1016/j.egypro.2014.03.251

15. Sayyah A, Horenstein M N, Mazumder MK. Energy yield loss caused by dust deposition on photovoltaic panels. Solar Energy. 2014, 107, 576-604. https://doi.org/10.1016/j. solener.2014.05.030

16. Kaldellis JK, Fragos P, Kapsali M. Systematic experimental study of the pollution deposition impact on the energy yield of photovoltaic installations. Renewable Energy. 2011, 36, 27172724. DOI: 10.1016/j.renene.2011.03.004.

17. Al-hasan AY, Ghoneim AA. A new correlation between photovoltaic panels efficiency and amount of sand dust accumulated on their surface. International Journal of Sustainable Energy. 2007, 24(4), 187-197. https://doi.org/10.1080/14786450500291834

18. Said S. Effects of dust accumulation on performances of thermal and photovoltaic flat-plate collectors. Applied Energy. 1990, 37(1), 73-84. DOI: 10.1016/0306-2619(90)90019-a.

19. Adinoyi MJ, Said SAM. Effect of dust accumulation on the power outputs of solar photovoltaic modules. Renewable Energy. 2013, 60, 633-636. DOI: 10.1016/j.renene.2013.06.014.

20. Ilse KK, Figgis BW, Werner M, Naumann V, Hagendorf C, Bagdahn J. Fundamentals of soiling processes on photovoltaic modules. Renewable and Sustainable Energy Reviews. 2018, 98, 239254. DOI: 10.1016/j.rser.2018.09.015.

21. Goossens D. Dry aeolian dust accumulation in rocky deserts: a medium-term field experiment based on short-term wind tunnel simulations. Earth Surface Processes and Landforms. 2000, 25(1), 41-57. DOI: 10.1002/(sici)1096-9837(200001)25:1<41::aid-esp47>3.0.co;2-6.

22. Goossens D, Kerschaever EV. Aeolian dust deposition on photovoltaic solar cells: the effects of wind velocity and airborne dust concentration on cell performance. Solar Energy. 1999, 66(4), 277-289. DOI: 10.1016/s0038-092x(99)00028-6.

23. Said SAM, Walwil HM. Fundamental studies on dust fouling effects on PV module performance. Solar Energy. 2014, 107, 328-337. http://dx.doi.org/10.1016/j.solener.2014.05.048

24. Sisodia AK, Mathur RK. Impact of bird dropping deposition on solar photovoltaic module performance: a systematic study in Western Rajasthan. Environmental Science and Pollution Research. 2019, 26, 31119-31132. https://doi.org/10.1007/s11356-019-06100-2

25. Yilbas BS, Ali H, Khaled MM, Al-Aqeeli N, Abu-Dheir N, Varanasi KK. Influence of dust and mud on the optical, chemical, and mechanical properties of a PV protective glass. Scientific Reports. 2015, 5, 15833 1-15833 12. DOI: https://doi.org/10.1038/srep158331

26. Aïssa B, Isaifan RJ, Madhavan VE, Abdallah AA. Structural and physical properties of the dust particles in Qatar and their influence on the PV panel performance. Scientific Reports. 2016, 6, 31467, 1-12. https://doi.org/10.1038/srep31467 
27. Ilse KK, Figgis BW, Werner M, Naumann V, HagendorfC, Pöllmann H, Bagdahn J. Comprehensive analysis of soiling and cementation processes on PV modules in Qatar. Solar Energy Materials and Solar Cells. 2018, 186, 309-323. https://doi.org/10.1016/j.solmat.2018.06.051

28. Pye K. Aeolian dust and dust deposits. Academic Press: San Diego. California, USA. 1987.

29. Yadav S, Rajamani V. Air quality and trace metal chemistry of different size fractions of aerosols in N-NW India-implications for source diversity. Atmospheric Environment. 2006, 40(4), 698 712. https://doi:10.1016/j.atmosenv.2005.10.005

30. Mani M, Pulipaka S, Kumar R. Characterization of power losses of a soiled PV panel in Shekhawati region of India. Solar Energy. 2016, 131, 96-106. DOI: 10.1016/j.solener.2016.02.033.

31. Hussain A, Batra A, Pachauri R. An experimental study on effect of dust on power loss in solar photovoltaic module. Renewables: Wind, Water, and Solar. 2017, 4(9), 1-13. https://doi. org/10.1186/s40807-017-0043-y

32. Paudyal BR, Shakya SR. Dust accumulation effects on efficiency of solar PV modules for off grid purpose: a case study of Kathmandu. Solar Energy. 2016, 135, 103-110. http://dx.doi. org/10.1016/j.solener.2016.05.046

33. Jiang H, Lu L, Sun K. Experimental investigation of the impact of airborne dust deposition on the performance of solar photovoltaic (PV) modules. Atmospheric Environment. 2011, 45, 4299-4304. DOI: 10.1016/j.atmosenv.2011.04.084

34. El-Shobokshy MS, Hussein FM. Degradation of photovoltaic cell performance due to dust deposition on to its surface. Renewable Energy. 1993, 3(6-7), 585-590. DOI: 10.1016/0960-1481(93)90064-n.

35. El-ShobokshyMS, Hussein FM.Effect ofdust with different physicalproperties on the performance of photovoltaic cells. Solar Energy. 1993, 51(6), 505-511. DOI: 10.1016/0038-092x(93)90135-b.

36. Saidan M, Albaali AG, Alasis E, Kaldellis JK. Experimental study on the effect of dust deposition on solar photovoltaic panels in desert environment. Renewable Energy. 2016, 92, 499-505. http://dx.doi.org/10.1016/j.renene.2016.02.031

37. Gholami A, Khazaee I, Eslami S, Zandi M, Akrami E. Experimental investigation of dust deposition effects on photo-voltaic output performance. Solar Energy. 2018, 159, 346-352. https://doi.org/10.1016/j.solener.2017.11.010

38. Appels R, Lefevre B, Herteleer B, Goverde H, Beerten A, Paesen R, De Medts K, Driesen J, Poortmans J. Effect of soiling on photovoltaic modules. Solar Energy. 2013, 96, 283-291. http:// dx.doi.org/10.1016/j.solener.2013.07.017 